ROCZNIKI HUMANISTYCZNE

Tom LXVIII, zeszyt 7 - 2020

DOI: http://dx.doi.org/10.18290/rh20687-2

MAŁGORZATA ABASSY

\title{
W NIEWOLI U KOŚCIEJA NIEŚMIERTELNEGO ALBO „SAMOTNOŚĆ SILNYCH KOBIET”: STUDIUM TREŚCI ROSYJSKIEJ BAJKI „MARIA MORIEWNA”
}

Kościej Nieśmiertelny to jedna $\mathrm{z}$ najbardziej rozpoznawalnych postaci wschodniosłowiańskiej mitologii i folkloru, a także współczesnej kultury popularnej. Pojawia się w bajkach - zarówno ludowych, jak i magicznych, filmach animowanych i fabularnych, na kartach komiksów. Jego niesłabnąca popularność stała się główną przesłanką do ponownego podjęcia namysłu nad obliczami tego archetypowego bohatera.

Badacze rosyjskiego folkloru proponują kilka interpretacji odnośnie do genezy bohatera: jako odzwierciedlenie wierzeń totemicznych (Frazer 623644), uosobienie sił przyrody (Toporkov 184; Afanas'ev 594), postać odzwierciedlającą elementy przemiany stosunków społecznych w układzie plemiennym oraz $\mathrm{w}$ zależności zdobywcy-podbijani (Rybakov 45-47; Anikin 129-130; Novikov 217-218); jako personifikację śmierci (Novichkova 275276; Meletinskij 314).

Ten ostatni kierunek interpretacji jest dla nas szczególnie interesujący ze względu na wątek inicjacji: śmierć jako nieodzowny moment przejścia do kolejnego etapu życia. Wiele tekstów folkloru wskazuje na związek małżeński kobiety i mężczyzny nie tylko jako akt społeczny, lecz także - a może przede wszystkim - jako głęboką przemianę psychologiczną i egzystencjalną, wymagającą rytualizacji oraz znajomości konsekwencji odbycia rytuału bądź

Dr hab. MAŁgorZata ABASSY, prof. UJ - Uniwersytet Jagielloński w Krakowie, Wydział Studiów Międzynarodowych i Politycznych, Instytut Rosji i Europy Wschodniej; adres do korespondencji: al. Mickiewicza 3, 31-120 Kraków; e-mail: malgorzata.abassy@uj.edu.pl. ORCID: https://orcid.org/0000-0002-9294-6156.

Dr habil. MaŁgORZATA ABASsy, prof. at UJ - Jagiellonian University in Krakow, Faculty of International and Political Studies, Institute of Russia and Eastern Europe; address for correspondence: al. Mickiewicza 3, 31-120 Kraków; e-mail: malgorzata.abassy@uj.edu.pl. ORCID: https://orcid.org/0000-0002-9294-6156. 
zaniechania go. Folklorystyczne obrazy Kościeja Nieśmiertelnego, odtwarzane we współczesnej kulturze popularnej i przetwarzane przez nią, skłaniają uczestnika kultury do refleksji o znaczeniu rytuałów inicjacyjnych.

Punkt wyjścia stanowi hipoteza, że Kościej ulega czasowej transformacji $\mathrm{w}$ zetknięciu $\mathrm{z}$ różnymi bohaterami i bohaterkami, przejawiając $\mathrm{w}$ ten sposób swą niejednoznaczną naturę, a jednocześnie skłaniając postacie, które spotkały go na swej drodze, do podjęcia decyzji o walce bądź jej zaniechaniu i tym samym do uczynienia kolejnego kroku na ścieżce swojego rozwoju. Warto podkreślić element zaniechania walki w przypadku postaci kobiet, gdyż - i to jest kolejna hipoteza badawcza - istnieją sytuacje, kiedy, paradoksalnie, rezygnacja z walki pozwala zwyciężyć. Właściwa decyzja jest oceniania przez pryzmat możliwości, jakie stwarza bohaterowi dla realizacji jego potencjału. Ów potencjał przejawia się w marzeniach i tęsknotach albo w początkowej decyzji, która zapoczątkowuje cykl wędrówki: Maria Moriewna wychodzi za mąż, nie realizuje się jednak jako żona, pozostając samotną wojowniczką (Mar'ya Morevna) ${ }^{1}$. W tym przypadku mamy wskazówkę, że zostało podjęte działanie, które powinno prowadzić do budowania relacji małżeńskiej i tworzenia rodziny. Tak się nie dzieje - z powodu obecności Kościeja. Wiemy jednak, że za działaniem bohaterki kryją się, uświadomione bądź nie, pragnienia i potrzeby. Przeniesienie potencjału marzenia jako energii do działania $\mathrm{w}$ planie rzeczywistości materialnej wymaga $\mathrm{w}$ tym przypadku pomocy ze strony innych bohaterów. Wszelkie decyzje, które prowadzą do uzyskania takiej pomocy, będą w niniejszych badaniach oceniane jako „właściwe”.

Podstawowe narzędzie badawcze stanowi schemat wędrówki bohatera oraz elementy morfologii bajki opracowane przez Włodzimierza Proppa. Analizy tekstu literackiego bajki Mar'ya Morevna pozwolą wskazać na momenty interakcji Kościeja i poszczególnych bohaterów, przyjęta zaś perspektywa wędrówki bohatera jako odzwierciedlenia cyklu jego wewnętrznej przemiany umożliwi rozpoznanie stawianych mu wyzwań, sposobu reagowania na nie i konsekwencji dla kolejnych kroków podjętej „wyprawy po skarb". W artykule punkt ciężkości spoczywa na relacjach damsko-męskich, stąd uwypuklenie Jungowskiej koncepcji archetypu.

Poniższa, obszerna prezentacja tekstów kultury, w których postać Kościeja występuje, służy do wykazania niesłabnącej popularności postaci Kościeja i, pośrednio, wskazuje na zasadność wyboru tego bohatera jako centrum rozważań, przy jednoczesnym odwołaniu się do samotności jako problemu współczesnej kobiety.

\footnotetext{
${ }^{1}$ Tłumaczenia fragmentów - jeśli nie zaznaczono inaczej - M.A.
} 
Materiały źródłowe, w których postać Kościeja albo jest pierwszoplanowa, albo stanowi element organizujący fabułę, to teksty bajek: Maria Moriewna (Mar'ya Morevna), Królewna-żabka (Carevna-lyagushka), Królewna-wąż (Carevna-zmeya), Iwanko-Niedźwiadko (Ivanko Medvedko), Kościej Nieśmiertelny (Koshchey Bessmertnyy), Iwan Bykowicz (Ivan Bykovich); filmy fabularne: Kościej Nieśmiertelny (Koshchey Bessmertnyy) oraz Ogień, woda i ... miedziane kominy (Ogon', voda i... mednye truby), Wesote czarodziejstwo (Veseloye volshebstvo), Noworoczne przygody Maszy i Witi (Novogodnie prikljuchenija Mashi i Viti), Tam, na nieznanych dróżkach (Tam, na nevedomykh dorozhkakh), Po deszczyku w czwartek (Posle dozhdichka $v$ chetverg), Na złotym ganku siedzieli ( $N a$ zlatom kryl'ce sideli), Bajka o zakochanym malarzu (Skazka pro vlyublennogo malarya), Liliowa kula (Liliovyy shar), Księga mistrzów (Kniga masterov), Cuda w Reszetowie (Chudesa v Reshetove), Legenda o Kościeju (Legenda o Koshcheye), Prawdziwa bajka (Real'naya skazka), Przygody w trzydziesiatym królestwie (Priklyucheniya v tridesyatom carstve), Ostatni bohater (Posledniy bogatyr'), a także filmy animowane: Królewna-żabka (Carevna Lyagushka, 1970), Bajka się opowiada (Skazka skazyvaetsja, 1970), Jabłka młodości (Molodil'nye yabloki, 1974), Baba Jaga przeciw! (Baba Yaga protiv!, 1980), Iwaszka z dworca pionierów (Ivashka iz dvorca pionerov, 1981), A w tej bajce byto tak (A v yetoy skazke bylo tak, 1984), Dwaj bohaterowie (Dva bogatyrja, 1989), Fantaści ze wsi Ugory (Fantazery iz derevni Ugory, 1994), Babka Jożka i inni (Babka Ezhka i drugie, 2006), Królewicz Iwan i szary wilk (Ivan Carevich i seryy volk, 2011), Królewny (Carevny, 2018).

Pod uwagę zostały wzięte teksty stanowiące elementy kultury ludowej bądź popularnej, pominięto natomiast bajki autorskie, w których postać Kościeja pojawia się, lecz które ograniczyły się do wąskiego kręgu odbiorców, jak Bajka o carze Berendeju, o jego synu królewiczu Iwanie, o podstępach Kościeja Nieśmiertelnego i wielkiej madrości królewny Marii, Kościejowej córki (Skazka o care Berendeye, o syne ego Ivanye-careviche, o hitrostyakh Koshcheja Bessmertnogo i o premudrosti Mar'i-carevny, Koshcheevoy docheri) Wasyla Żukowskiego, $W$ dót zaczarowanej rzeki (Vniz po volshebnoy reke) Edwarda Uspienskiego, Rustan i Ludmiła (Ruslan i Lyudmila) Aleksandra Puszkina, Stowik-Rozbójnik przeciwko Kościejowi Nieśmiertelnemu $i$ Wowce-Krzyżonośce (Solovey Razboynik protiv Kashcheya i Vovki-krestonosca) Władysława Rezanowa.

Istnieje również bogaty korpus tekstów literackich, nienależących do gatunku bajki, w których występują postacie wykazujące związki typo- 
logiczne z postacią Kościeja. Zostały one pominięte w niniejszych analizach ze względu na to, że nie stanowią części kultury popularnej. Nawiązanie do postaci Kościeja, zrodzonej przez słowiański folklor, znajdziemy w tytule i treści opery Nikołaja Rimskiego-Korsakowa Kościej Nieśmiertelny (Koshchey Bessmertnyy) oraz w balecie Igora Strawińskiego Żar-ptak (Zhar ptica). Przytoczone przykłady świadczą o żywotności archetypu, przejawiającego się w postaci Kościeja również w kulturze współczesnej z nieco odmiennymi, wydawałoby się, wyzwaniami i problemami niż te, które były charakterystyczne dla dawnych wieków. Co zatem decyduje o popularności Kościeja jako bohatera tak wielu dzieł kultury i jak wygląda jego „podróż przez wieki": czy jego metamorfozy wynikają z ducha czasów, czy też są pozorne, a po konfrontacji z bohaterem lub bohaterką Kościej wraca do swojej pierwotnej postaci? Jakie możliwości rozwoju daje bohaterce spotkanie $\mathrm{z}$ tym antagonistą i jakie konsekwencje rodzi podjęcie z nim walki?

Poruszanie się w obszarze tak skomplikowanego węzła problemów natury psychologiczno-egzystencjalnej, przy jednoczesnym przemieszczaniu się między różnymi epokami i odmiennymi rodzajami tekstów wymaga na wstępie przygotowania precyzyjnego narzędzia badawczego oraz zdefiniowania podstawowych pojęć.

Pierwszym z nich jest uproszczony schemat bajki magicznej, zawierający zwięzłe omówienie jej najważniejszych elementów - na podstawie opracowań Włodzimierza Proppa. Znajdziemy wśród nich głównego bohatera wraz z jego kręgiem akcji, antagonistów i protagonistów, magiczne przedmioty oraz zwierzęta (Propp 60-63). Wykorzystanie go jako narzędzia analitycznego pozwala bez wszelkich wątpliwości stwierdzić, że Kościej Nieśmiertelny jest antagonistą rzeczywistym, to znaczy pragnie zniszczyć bohaterów i pochłonąc ich potencjał. Stanowi przeciwieństwo antagonisty pozornego, który pojawia się jedynie po to, by poprzez stawianie wyzwań pomóc bohaterowi wydobyć jego pozytywne cechy i wzmocnić te, które okażą się nieodzowne do dalszej wędrówki. W świetle dokonanego zestawienia uprawniony jest wniosek, że bohater, który znalazł się w mocy antagonisty rzeczywistego, może zostać uratowany jedynie przez innego bohatera. W konsekwencji szlak wędrówki kobiety i mężczyzny przeplata się, a samorealizacja jednego z nich jest nierozerwalnie związana $\mathrm{z}$ losami drugiego.

Drugie z kolei narzędzie badawcze to schemat wędrówki bohatera, przygotowany na podstawie wyników badań takich znawców tematu, jak wspomniany wyżej Włodzimierz Propp, Maria-Gabriel Wosien czy John Campbell. Pierwszy etap znamionuje brak lub strata, która skłania bohatera do 
wyruszenia $\mathrm{w}$ drogę. Po nim następuje przygotowanie do wyprawy oraz opuszczenie rodzinnego domu, królestwa czy miejsca w rzeczywistości materialnej. Kolejny etap stanowi przekroczenie granicy między światami: materialnym i duchowym, „tym” i „tamtym”, królestwem żywych i umarłych. Spotkanie protagonistów i antagonistów to kamienie milowe wędrówki bohatera, w czasie której sprawdzane są jego cechy takie jak dobroć, mądrość i odwaga. Pozorni antagoniści oraz prawdziwi i pozorni protagoniści przygotowują bohatera do przełomowego etapu, jakim jest zmierzenie się z prawdziwym antagonistą. To walka na śmierć i życie, a ponieważ bajka magiczna pokazuje cały cykl przemiany, często nie kończy się ona wraz ze śmiercią bohatera, lecz toczy się dalej, stwarzając okoliczności, by bohater się odrodził i na nowo podjął wędrówkę.

W procesie analizy treści bajek w postaci tekstu literackiego oraz obrazu filmowego będziemy się poruszać między punktami orientacyjnymi wyznaczonymi przez kluczowe pojęcia, takie jak: archetyp, samotność, kobiecość/ męskość. Pierwsze z nich odsyła nas do teorii archetypu opracowanej przez Gustawa Junga, w myśl której archetyp jest obrazem pierwotnym, wspólnym dla całej ludzkości, charakteryzującym przede wszystkim obszar nieświadomości.

Pojęcie archetypu (...) zostało wywiedzione $\mathrm{z}$ wielokrotnie powtarzanych obserwacji, jak na przykład ta, że mity i bajki literatury światowej zawierają ściśle określone motywy, które pojawiają się zawsze i wszędzie. Jednocześnie te same motywy spotykamy w fantazjach, snach, deliriach i urojeniach wspólczesnego człowieka. Te właśnie typowe obrazy i związki nazywamy wyobrażeniami archetypowymi. Im są wyraźniejsze, tym jaskrawiej uwidacznia się to, że towarzyszy im szczególnie intensywne zabarwienie emocjonalne (...). Wywierają na nas wrażenie, są sugestywne i fascynujące. Biorą one swój początek w archetypie, który - sam w sobie - wymyka się przedstawieniu, jest nieświadomą praformą, stanowiącą - jak się wydaje - część struktury psyché, może przeto pojawiać się zawsze i wszędzie. (Jung 199)

Chociaż struktura archetypu jest bipolarna, to znaczy pierwotny obraz zawiera w sobie zarówno potencjał twórczy, jak i destrukcyjny, bohaterowie przejawiający jego cechy mogą prezentować zachowania bardziej jednoznaczne. Przykład Kościeja Nieśmiertelnego jest w tym przypadku znamienny: mimo że jest charakteryzowana przez przymiotnik „nieśmiertelny”, postać ta ginie z rąk bohatera. Co więcej, nieustannie i konsekwentnie dąży do zniszczenia zarówno pojmanych przez siebie kobiet, pozbawiając je wolności utożsamionej z możliwością wędrowania, czyli rozwoju, jak i męskich 
bohaterów. Próba dowodzenia tezy o bipolarności bohatera zrodziłaby obserwację, że jego drugim biegunem jest pierwiastek żeński - w osobie Baby Jagi, również manifestujący się jako moc wywołująca destrukcję, tyle tylko, że w sposób pośredni: Iwan-królewicz zabija Kościeja dzięki koniowi, otrzymanemu od Baby Jagi (Mar'ya Morevna).

Bipolarna struktura archetypów oraz komplementarność bajkowych antagonistów, Kościeja i Baby Jagi, kieruje uwagę badacza ku szerszemu tłu pojęć kobiecości i męskości. Nie tylko są one archetypowe, ale też wymykają się próbom systematyzacji czy definiowania. Stanową źródło całego spektrum symboli i cech, które dopełniają się wzajemnie, jednocześnie będąc swoimi przeciwieństwami. Ów swoisty paradoks komplementarności przeciwstawnych cech można odnieść do Jungowskiej koncepcji animy i animusa jako pierwotnych wyobrażeń kobiecości i męskości. Problem przenikania się archetypów został wyeksponowany przez Junga jako jedna z najważniejszych cech procesu transformacji - zarówno w obrębie jednej postaci, jak też na ich styku (Jung 225). Kobiecość jako archetypowa cecha ujawnia się w kontakcie z męskościa. Fakt ów sprawia, że wszelkie próby definiowania jej w oderwaniu od kontekstu, tworzonego przez postać męską wraz z przypisanym jej zestawem cech i zachowań, są z góry skazane na niepowodzenie. Ponadto istota kobiecości i męskości wymyka się ogólnym definicjom - ujawniają one swoje specyficzne aspekty jedynie w ramach konkretnego studium przypadku. Wysnuty wniosek skłania nas ku stwierdzeniu, że każda z bohaterek analizowanych utworów, reprezentująca szeroko rozumianą i niedefiniowalną w pełni kobiecość, przyczyni się do wydobycia innych cech z ogromnego zbioru elementów, który można określić nieprecyzyjnym pojęciem męskości u bohatera. W tym wypadku Kościej będzie stanowił spiritus movens poszukiwań, w których wyniku kobiecość i męskość ostatecznie połączą się w parę - jako mąż i żona, niekoniecznie w tradycyjnym rozumieniu społecznych ról z przypisanymi im zadaniami do wykonania na polu wspólnoty, rodziny, rodu, a bardziej jako pełnia psychiczno-duchowa. Zgodnie z klasycznym schematem bajki magicznej ostateczny cel wędrówki nierozerwalnie łączy się z pierwotnym uczuciem braku lub wydarzeniem straty. Miłość, którą bohater spotyka na swojej drodze całkowicie nieoczekiwanie, zostaje mu zabrana (Mar'ya Morevna). Między tym początkowym momentem przedsmaku spełnienia, a spełnieniem, które - według przekazu bajki - ma stać się ostatecznym i trwałym, rozciąga się ogromny obszar samotnych poszukiwań. Samotność uznaliśmy za jeden z najważniejszych, chociaż jak dotąd zdecydowanie zbyt słabo wyeksponowany przez 
badaczy folkloru i post-folkloru element bajek i, szerzej, historii o wędrówkach bohaterów. Jest to termin wywodzący się z filozofii i oznaczający sytuację egzystencjalną, gdy człowiek staje wobec świadomości, że nie jest samowystarczalny i potrzebuje do spełnienia swego losu obecności drugiego człowieka.

Więzi międzyludzkie są darem. Człowiek jako jedyna wolna istota może zostać opuszczony przez innych. Ale może także jako jedyna wolna istota odwrócić kierunek swojego własnego dramatu, podejmując wysiłek przemiany swego opuszczenia $\mathrm{w}$ więź. To jedyna szansa, aby poprzez zawierzenie i dar nadać sens swojej samotności. (Gadacz 109)

Tęsknota za obecnością drugiego człowieka najmocniej ujawnia się w obliczu spraw ostatecznych, reprezentowanych przez Erosa i Thanatosa. Zarówno miłość, jak i śmierć wymagają fundamentalnej transformacji: umierania i odradzania się po wielokroć i na wiele sposobów. A zatem wędrówka bohatera po miłość to nauka dobrego umierania oraz manifestacji chęci nieustannego powracania do życia. W takiej perspektywie Kościej jest jednocześnie Erosem i Thanatosem.

Warto wybrane pojęcia uzupełnić o omówienie semantyki frazy silna kobieta. W perspektywie przyjętej w niniejszym artykule oraz w sposób intencjonalny uwarunkowanej doborem materiału źródłowego pragniemy zwrócić uwagę na wagę kulturowych wzorców wywodzących się z archetypów. W dużej mierze są one nieuświadamiane, dlatego współcześnie bardzo często utożsamia się style manifestacji siły kobiecej i męskiej, co w świetle archetypowych cech jest błędem. Przekaz bajki magicznej jest inny: kobieca siła manifestuje się w rezygnacji z postawy wojowniczki oraz w przyzwoleniu, by ten obszar zajął mężczyzna. Bohaterki bajek, w których pojawia się Kościej, nie mogą uznać mężczyzny za partnera dopóty, dopóki, paradoksalnie, będąc fizycznie w niewoli u Kościeja i skazanymi na bierność - jak Maria Moriewna - nie uzyskają szansy, by uwolnić się od męskiego stylu bycia, skupionego na aktywności i walce. Samotność w tym przypadku wynikałaby z zajęcia przez kobietę miejsca należnego mężczyźnie w archetypowej wędrówce po miłość i spełnienie.

Interesujący przy tym i wart pogłębionej refleksji jest fakt, że w ludowym przekazie zawarta została informacja o istnieniu sprzężenia zwrotnego między kobiecością a męskością jako jakościami dopełniającymi się: porwana przez Kościeja bohaterka oczekuje uwolnienia - bohater wyrusza w drogę i już na jednym z początkowych etapów potrzebuje zwrócić się ku kobiecości, by 
uzyskać pomoc w postaci konia, podpowiedzi, rady. Badacze wielokrotnie zwracali uwagę na ten szczególny rys bajki magicznej: bohaterowi pomagają kobiety lub mężczyźni, wywodzący się z linii żeńskiej - szwagrowie bądź bracia uprowadzonej przez Kościeja ukochanej (Anikin 461).

Analiza treści materiału źródłowego wskazuje na dwojakiego rodzaju bohaterki trafiające do niewoli u Kościeja: są to albo wojowniczki - i w tym przypadku niewola ma charakter metaforyczny, albo kobiety-trofea - zabrane przez Kościeja do jego posiadłości. Bardzo często obydwa typy niewoli dotyczą jednej bohaterki, co pozwala stwierdzić, że zniewolenie jest cechą immanentną postaci, a nie tylko czasowym wydarzeniem manifestującym się rzeczywistym pojmaniem.

Bajką reprezentatywną dla omawianego tematu - silnej kobiety w niewoli u Kościeja i jej samotności, którą przełamać może jedynie rezygnacja z manifestowania własnej siły na „męski” sposób, poprzez walkę i poleganie wyłącznie na sobie - jest Maria Moriewna. Analizie jej treści poświęcimy szczególną uwagę.

Iwana-królewicza nie przeraża wojowniczość - by nie rzec krwiożercze usposobienie - potencjalnej wybranki. Jeszcze przed spotkaniem wie, że Maria Moriewna nie zna litości: „Wyruszył w drogę, szedł, szedł i widzi: leży w polu mnóstwo wojów zabitych. Pyta Iwan-królewicz: Czy jest tu kto żyw? Odezwij się: kto pobił tak wielkie wojsko? Odpowiedział mu żywy człowiek: Całe to wielkie wojsko pobiła Maria Moriewna, piękna królewna" (Mar'ya Morevna). Istotny też jest fakt, że to nie on wybiera, lecz zostaje wybrany: „(...) dwie-trzy noce spędził w namiotach. Spodobał się Marii Moriewnie i ożenił się z nią. Maria Moriewna, piękna królewna wzięła go do swojego królestwa" (Mar'ya Morevna). Metafora wejścia mężczyzny w świat kobiety-wojowniczki wskazuje na zamianę ról: to Iwan ma zostać w domu, a jego żona zagospodarowuje świat zewnętrzny. Wprawdzie nie został on uprowadzony siłą, jak stało się to w przypadku bohaterek porwanych przez Kościeja, niemniej jednak podobieństwo jest znaczące - zasady wspólnego życia ustala kobieta: żona przykazuje mężowi, by pod żadnym pozorem nie zaglądał do spiżarni. Tam właśnie ukrywa swoją tajemnicę - spragniony szkielet. Symbol wody bywał już omawiany wielokrotnie (Vinogradova 32-60), dlatego zwrócimy uwagę tylko na dwie jego cechy, istotne w analizowanym kontekście: powiązanie ze światem emocji i łez oraz przeciwieństwo ognia, kojarzonego tradycyjnie z siłą męską. Walka i rezygnacja $\mathrm{z}$ odbierania świata przez pryzmat emocji, reprezentowane przez dwanaście łańcuchów trzymających Kościeja przykutego do ściany, to zarazem symbole niewoli samej 
Marii Moriewny. W pierwszym spotkaniu Iwana z Kościejem ujawnia się dobroć bohatera, chociaż logika podpowiada, by nazwać gest napojenia szkieletu naiwnym bądź zwyczajnie głupim: Iwan nie zadaje pytań o przyczyny, dla których Kościej znalazł się w spiżarni; nie zastanawia się też, z jakiego powodu Maria Moriewna pozostawiła więźnia bez wody i pożywienia przez całe dziesięć lat. Zgodnie z logiką bajki magicznej ten dobry uczynek pociąga za sobą stratę i zmusza bohatera, by wyruszył w drogę, zdobywając i wydobywając z siebie cechy, których mu brak, by mógł zająć należne sobie, zgodnie z logiką archetypu męskości, miejsce. Wolny i ulatujący Kościej woła: „Teraz już nigdy nie zobaczysz Marii Moriewny, jak i uszu swoich (...) I niczym straszny wicher wyleciał przez okno, dogonił po drodze Marię Moriewnę, piękną królewnę i uniósł do siebie" (Mar'ya Morevna).

Wskazówką, że zniewolenie kobiety przez antagonistę ma wymiar wewnętrzny, jest fragment bajki mówiący, że Maria Moriewna nie przebywa w zamknięciu: „Kiedy zobaczyła swojego miłego, rzuciła się mu na szyję i przemówiła" (Mar'ya Morevna). Po krótkiej wymianie zdań małżonkowie: „Zebrali się i odjechali, a Kościej na polowaniu był” (Mar'ya Morevna).

Brzemiennym w znaczenia jest motyw braku pośpiechu pomimo, wydawałoby się, wagi zadań oczekujących wypełnienia: Iwan w drodze po swoją żonę gości u każdej ze swoich sióstr i szwagrów po trzy dni, Kościej, za radą swojego konia, obsiewa pola pszenicą, czeka aż ona wyrośnie, przystępuje do zbiorów, miele pszenicę na mąkę, piecze z niej pięć pieców chleba i zjada je, zanim wyruszy w pogoń (Mar'ya Morevna). Przeznaczeniu nie można umknąć i ważniejsze jest właściwe postępowanie niż osiągnięcie celu. Można wręcz wywnioskować, że powodzenie realizacji zamiaru zawiera się w samym przygotowaniu: Iwan nie wie, że czas spędzony u szwagrów zaowocuje otrzymaniem pomocy, natomiast Kościej wie, że dopóki Maria Moriewna pozostaje w jego mocy, w żaden sposób nie zdoła mu umknąć i czas nie odgrywa w tym przypadku żadnej roli.

Każde ze spotkań małżonków i podjęta próba ucieczki wskazują na rosnące zaangażowanie Iwana: przy drugiej próbie, gdy słyszy od żony przestrogę, odpowiada: „To chociaż kawałek drogi przejedziemy razem”, a przy trzeciej, stając w obliczu groźby śmierci, stwierdza: „Niech zabije, ja bez ciebie nie mogę żyć" (Mar'ya Morevna). Niemniej jednak sama odwaga nie wystarcza, by odzyskać ukochaną. Iwan ginie, a bajkowa narracja toczy się w kierunku odsłonięcia kolejnej prawdy: uwolnienie kobiety spod władzy Kościeja wymaga od mężczyzny, by ten zwrócił się ku prastarej kobiecej mądrości i otrzy- 
mał ją nie dlatego, że poprosi - gdyż okazuje się to być niewystarczające lecz dlatego, że wykorzystuje intuicję, głębokie rozumienie sytuacji. Zdobycie przez Iwana konia jest rezultatem cierpliwości, sprytu i współczucia oraz zrozumienia tego, co niepozorne i, wydawałoby się, nieprzydatne. Bohater sięga zatem do sposobu widzenia typowego dla kobiet: zagłębiania się w istotę rzeczy, przekraczania gry pozorów.

Co w tym czasie robi Maria Moriewna? Wytrwałość Iwana stanowi w tym wypadku część binarnej pary z czekaniem królewny. Jedno bez drugiego nie miałoby sensu. Bajka pokazuje zatem, że czekanie kobiety nadaje wartość działaniom mężczyzny, natomiast męska wytrwałość sprawia, że kobiece czekanie nie idzie na marne.

W trakcie analizy tekstów ujawniło się jeszcze jedno zestawienie paralelnych i dopełniających się, jeśli mowa o toku akcji, motywów: Iwan-królewicz poszukuje wsparcia u kobiet, głównie u Baby Jagi, natomiast Maria Moriewna sięga do zasobów Kościeja, dopytując go, skąd wziął tak szybkiego konia i w jaki sposób przebywa ognistą rzekę. W rezultacie Baba Jaga, antagonista mężczyzny, i Kościej nieśmiertelny, antagonista kobiety, odsłaniają swoje tajemnice, by uwolnienie Marii Moriewny stało się możliwe.

Pozwalając Iwanowi zabić Kościeja, Maria Moriewna rezygnuje w symboliczny sposób z bycia wojowniczką, a jednocześnie przejmuje siłę swojego antagonisty, symbolizowaną przez jego konia.

Ofiarami Kościeja padają kobiety zamężne lub szykujące się do zamążpójścia (Koshchey Bessmertnyy), chociaż jeśli spojrzymy na problem w szerszym kontekście, to okaże się, że pokrzywdzeni zostają też mężczyźni, którym obiecano piękną królewnę za żonę (Koshchey Bessmertnyy). Bajkowa narracja przyznaje kobiecie rolę pasywną, w najlepszym razie - rolę pomocnicy, podstępem zdobywającej potrzebną informację. We wszystkich bajkach znajdziemy wyraźny przekaz, że od momentu porwania przez Kościeja bohaterka jest zmuszona do polegania na innych.

Wspomniane wyżej wątki, charakterystyczne dla relacji kobiecości i męs$k o s ́ c i$ w bajkach, odnajdziemy również w filmach animowanych i fabularnych. Bohater deklaruje wprost cel swojej wyprawy - uwolnić piękną królewną i zabić Kościeja (Dva bogatyrya, 1989)2, ona czeka na ratunek, a później wracają do króla-ojca i, wziąwszy ślub, żyją długo i szczęśliwie.

Podsumowując, należy stwierdzić, że jedną z sytuacji, które prowokują pojawienie się Kościeja Nieśmiertelnego jest ta, w której kobieta zaczyna tęsknić za mężczyzną. Właśnie owa tęsknota stanowi swoistego rodzaju

\footnotetext{
${ }^{2}$ Liczba oznacza rok premiery filmu.
} 
„zew”, przywołujący odwiecznego antagonistę. Ponadto silna kobieta jest nosicielką cech Kościeja, przejawiających się w jej dążeniach do otwartej konfrontacji i walki o swoje. Reprezentuje typ kobiety-wojowniczki. Paradoksalnie parą dla kobiety zniewolonej przez Kościeja jest mężczyzna „głupi” i dobry. Warto przypomnieć, że wspomniana wyżej niewola manifestuje się na dwa sposoby: jako fizyczne pojmanie oraz jako uwewnętrznione cechy antagonisty.

Największym wyzwaniem dla silnej kobiety jest całkowite oddanie swojego losu w ręce innych, w tym ukochanego mężczyzny, z wiarą, że zrobią oni to, co do nich należy: właściwie rozpoznają stawiane im wyzwania i odpowiedzą na nie w adekwatny sposób. Uniwersalna mądrość bajki sprowadza się w tym przypadku do przekazu, że przełamanie samotności silnej kobiety zależy od jej umiejętności zawierzenia mężczyźnie. Byłby to jednak przekaz niepełny, gdyby ograniczyć go wyłącznie do kobiety, gdyż bajka niesie informację również dla mężczyzny, by podejmując próbę uwolnienia swojej kobiety, udał się po mądrość do innych kobiet.

Warto nadmienić, że współczesny przekaz historii o Kościeju Nieśmiertelnym zawiera interesujący rys kulturowy - kobietom ruszają na pomoc inne kobiety: Katia znajduje czarodziejską trawę, która umożliwia zdjęcie zaklęcia z Pięknej Wasylisy, a pomocy i wskazówek poszukuje w księdze (Veseloye volshebstvo, 1969). Jest to wątek wyznaczający ciekawą perspektywę badawczą. Podobnie jak próby odebrania mocy archetypowemu obrazowi Kościeja poprzez nadawanie postaci cech komicznych (Baba Yaga protiv!, 1979).

Sam Kościej podlega czasowym przemianom, przybierając rożne postacie - by zmylić bohatera, zwieść go w pułapkę, uniknąć własnej „śmierci”. Nie jest to jednak bohater, który ewoluuje. Warto również zaznaczyć, że śmierć Kościeja jest śmiercią pozorną - odradza się on po wielokroć. Ten wątek wymaga dalszych dociekań badawczych.

Za względu na wielość kontekstów kulturowych Kościeja jako symbolu zjawisk i procesów, niektóre możliwości interpretacji zostały jedynie zasygnalizowane jako dalsze perspektywy badawcze. Oto niektóre z nich:

- Analiza fenomenu samotności „silnej kobiety”, zniewolonej przez cechy reprezentowane archetypową postacią Kościeja, w ujęciu filozoficznym. Wówczas bajka nie byłaby traktowana wyłącznie jako element obrzędu inicjacyjnego i interpretowana $\mathrm{w}$ oparciu o Jungowską koncepcję archetypu. Analiza z punktu widzenia egzystencjalnych zadań człowieka obejmowałaby namysł nad wertykalnym kierunkiem ludzkich działań i procesem autotranscendencji. 
- Porównanie treści bajek jako utworów literackich z treściami filmów fabularnych, z naciskiem na formę przekazu i zakładany typ relacji między nadawcą a odbiorcą. Ten kierunek badań wymagałby współpracy kulturoznawcy ze specjalistą w dziedzinie mediów i kultury wizualnej.

- Interesującym zadaniem badawczym byłyby analizy kulturoznawczo-socjologiczne dotyczące realizacji egzystencjalnego celu, jakim jest „stawanie się” (w ujęciu m.in. Gariela Marcela czy Mikołaja Bierdiajewa ) w ramach jego ról społecznych. Tutaj też potrzebna jest współpraca kulturoznawcy oraz socjologa i wzajemne wzbogacenie aparatu teoretyczno-metodologicznego.

\section{BIBLIOGRAFIA}

ŹRÓDŁA (W JĘZYKU ROSYJSKIM)

A. BAJKI

„Иван Быкович”. Народные русские сказки А.Н. Афанасьева в трех томах. Составили Лев Бараг и Юрий Новиков, „Наука”, 1984-1985, t. 1, ss. 225-231 [„,Ivan Bykovich”. Narodnyye russkiye skazki A.N. Afanas'yeva v trekh tomakh. Sostavili Lev Barag i Yuriy Novikov, „Nauka” 1984-1985, t. 1, ss. 225-231].

„Иванко Медведко”. Народные русские сказки А.Н. Афанасьева в трех томах. Составили Лев Бараг и Юрий Новиков, „Наука”, 1984-1985, t. 1, ss. 270-272 [„Ivanko Medvedko". Narodnyye russkiye skazki A.N. Afanas'yeva v trekh tomakh. Sostavili Lev Barag i Yuriy Novikov, „Nauka” 1984-1985, t. 1, ss. 270-272].

„Кощей Бессмертный”. Народные русские сказки А.Н. Афанасьева в трех томах. Составили Лев Бараг и Юрий Новиков, „Наука”, 1984-1985, t. 1, ss. 285-300 [„,Koshchey Bessmertnyy”. Narodnyye russkiye skazki A.N. Afanas'yeva v trekh tomakh. Sostavili Lev Barag i Yuriy Novikov, „Nauka” 1984-1985, t. 1, ss. 285-300].

„Марья Моревна”. Народные русские сказки А.Н. Афанасьева в трех томах. Составили Лев Бараг и Юрий Новиков, „Наука”, 1984-1985, t. 1, ss. 300-305 [„Mar’ya Morevna”. Narodnyye russkiye skazki A.N. Afanas'yeva v trekh tomakh. Sostavili Lev Barag i Yuriy Novikov, „Nauka” 1984-1985, t. 1, ss. 300-305].

„Царевна змея”. Народные русские сказки А.Н. Афанасьева в трех томах. Составили Лев Бараг и Юрий Новиков, „Наука”, 1984-1985, t. 2, ss. 268-270 [„Carevna-zmeya”. Narodnyye russkiye skazki A.N. Afanas'yeva v trekh tomakh. Sostavili Lev Barag i Yuriy Novikov, „Nauka” 1984-1985, t. 2, ss. 268-270].

„Царевна-лягушка”. Народные русские сказки А.Н. Афанасьева в трех томах. Составили Лев Бараг и Юрий Новиков, „Наука”, 1984-1985, t. 2, ss. 260-268, [„Carevnalyagushka". Narodnyye russkiye skazki A.N. Afanas'yeva $v$ trekh tomakh. Sostavili Lev Barag i Yuriy Novikov, „Nauka” 1984-1985, t. 2, ss. 268-270].

B. Filmy ANimowane

A в этой сказке было так. Режиссер Лидия Суриковая, Экран, 1984, [A v etoy skazke bylo tak. Rezhisser Lidiya Surikovaya. Ekran, 1984], www.youtube.com/watch?v=GG9r7Duh Nd8. Dostęp 1.03.2020. 
Баба Яга против! Режиссер Владимир Пекарь, Союзфильм, 1979 [Baba Yaga protiv!. Rezhisser Vladimir Pekar'. Sojuzfil'm, 1979], www.youtube.com/watch?v=zyWKIjFSqjY. Dostęp 1.03.2020.

Бабка Ежка и другие. Режиссер Валерий Угаров, United Multimedia Projects, 2006 [Babka Ezhka i drugiye. Rezhisser Valeriy Ugarov, United Multimedia Projects, 2006], www. youtube.com/watch?v=dZLNEsY-y6U. Dostęp 1.03.2020.

Два богатыря. Режиссер Александр Давыдов. Союзмультфильм 1989 [Dva bogatyrya. Rezhisser Aleksandr Davydov. Sojuzmul'tfil'm 1989], www.youtube.com/watch?v=81Q4 Nbh61lc. Dostęp 1.03.2020.

Иван-ияаревич и серый волк. Режиссер Владимир Торопчин, Студия Мельница, СТВ, 2011 [Ivan-carevich i seryy volk. Rezhisser Vladimir Toropchin. Studija Mel'nica, STV, 2011], www.youtube.com/watch?v=WRzEzLlD8Nk. Dostęp 1.03.2020.

Ивашка из двориа пионеров. Режиссер Геннадий Сокольский, Союзмультфильм, 1981 [Ivashka iz dvorca pionerov. Rezhisser Gennadiy Sokol'skiy. Sojuzmul'tfil'm, 1981], www.youtube.com/watch?v=3fdiJlPex8s. Dostęp 1.03.2020.

Молодильные яблоки. Режиссер Иван Аксенчук, Союзмультфильм, 1974 [Molodil'nyye yabloki. Rezhisser Ivan Aksenchuk, Sojuzmul'tfil'm, 1974], www.youtube.com/watch?v= jDEIdCHXOWU. Dostęp 1.03.2020.

Сказка сказывается. Режиссер Иван Аксенчук, Союзмультфильм, 1970 [Skazka skazyvaetsya. Rezhisser Ivan Aksenchuk, Sojuzmul'tfil'm, 1970], www.youtube.com/watch?v=K86 RCPWiwoQ. Dostęp 1.03.2020.

Фантазеры из деревни Угоры. Режиссер Леонид Носырев, Союзмультфильм, 1994 [Fantazery iz derevni Ugory. Rezhisser Leonid Nocyrev, Sojuzmul'tfil'm, 1994], www.youtube.com/ watch? $\mathrm{v}=\mathrm{fDFmtNmjJt8.} \mathrm{Dostęp} \mathrm{1.03.2020.}$

Царевна-лягушка. Режиссер Михаил Цехановский, Союзмультфильм, 1954. [Carevna-lyagushka. Rezhisser Mihail Cehanovskiy, Sojuzmul'tfil'm, 1954], www.youtube.com/ watch?v= SBo FKyn3qmM. Dostęp 1.03.2020.

Царевны. Режиссеры Елена Галдобина, Константин Бронзит и Дарина Шмидт, Студия Мельница, СТВ, СТС, с первого сентября 2018. [Carevny. Rezhissery Elena Galdobina, Konstantin Bronzit i Darina Shmidt, Studiya Mel'nica, STV, STS, s pervogo sentyabrya 2018], ctc.ru/projects/multiki/tsarevny/. Dostęp 1.03.2020.

$$
\text { C. Filmy fabularne }
$$

Веселое волшебство. Режиссер Борис Рыцарев, Киностудия им. М. Горького, 1969. [Vesoloye volshebstvo. Rezhisser Boris Rycarev, Kinostudiya im. M. Gor'kogo, 1969], www.youtube. $\mathrm{com} /$ watch?v=0E4qIm0zzvk. Dostęp 1.03.2020.

Книга мастеров. Режиссер Вадим Соколовский, Walt Disney Pictures, 2009 [Kniga masterov. Rezhisser Vadim Sokolovskiy, Walt Disney Pictures, 2009], www.youtube.com/watch?v= 1TZTWxe32DQ. Dostęp 1.03.2020.

Кощей Бессмертный. Режиссер Александр Роу. Союздетфильм, 1944 [Koshchey Bessmertnyy. Rezhisser Aleksandr Roy, Sojuzdetfil'm 1944], www.youtube.com/watch?v=QF LQn _vU6Iw. Dostęp 1.03.2020.

Лиловый шар. Режиссер Павел Арсенев, Киностудия им. М. Горького 1988 [Lilovyy shar. Rezhisser Pavel Arsenev, Kinostudiya im. M. Gor'kogo 1988], www.youtube.com/ watch?v=ZFiimGM6z0g. Dostęp 1.03.2020. 
На златом крыльце сидели. Режиссер Борис Рыцарев, Киностудия им. М. Горького 1986 [Na zlatom kryl'ce sideli. Rezhisser Boris Rycarev, Kinostudiya im. M. Gor'kogo 1986]. https://www.culture.ru/movies/598/na-zlatom-krylce-sideli. Dostęp 1.03.2020.

Новогодние приключения Маши и Вити. Режиссеры Игорь Усов и Геннадий Казанский, Киностудия Ленфильм, 1975 [Novogodnie priklyucheniya Mashi i Viti. Rezhissery Igor' Usov i Gennadiy Kazanskiy, Kinostudiya Lenfil'm, 1975], hdrezka.ag/films/fantasy/ 16299-novogodnie-priklyucheniya-mashi-i-viti.html. Dostęp 1.03.2020.

Огонь, вода и ... медные трубы. Режиссер Александр Роу, Киностудия им. М. Горького, 1967 [Ogon', voda i ... mednyye truby. Rezhisser Aleksandr Roy, Kinostudiya im. M. Gor'kogo, 1967], www.youtube.com/watch?v=K31G6up6q50. Dostęp 1.03.2020.

Приключения в тридесятом ичарстве. Режиссер Валерия Ивановская, Киностудия Юность, 2010 [Priklyucheniya v tridesyatom tsarstve. Rezhisser Valeriya Ivanovskaya, Kinostudiya Yunost', 2010], www.youtube.com/watch?v=D8eSGMv9TVA. Dostęp 1.03.2020.

После дождичка в четверг. Режиссер Михаил Юзовский, Киностудия им. М. Горького, 1986 [Posle dozhdichka v chetverg. Rezhisser Mihail Yuzovskiy, Kinostudiya im. M. Gor'kogo, 1986], www.youtube.com/watch?v=msUqoKZdKJ0. Dostęp 1.03.2020.

Последний богатырь. Режиссер Дмитрий Дьяченко, Walt Diseny Pictures; Yellow, Black and White, 2017 [Posledniy bogatyr'. Rezhisser Dmitriy D'yachenko, Walt Diseny Pictures; Yellow, Black and White, 2017], kinokrad.co/319798-posledniy-bogatyr.html. Dostęp 1.03.2020.

Реальная сказка. Режиссер Андрей Мармонтов, Централ Партнершип, 2011 [Real'naya skazka. Rezhisser Andrey Marmontov, Central Partnership, 2011], www.youtube.com/ watch?v=DafABMMLbzU. Dostęp 1.03.2020.

Сказка про влюбленного маларя. Режиссер Надежда Кошеверова, Ленфильм, 1986 [Skazka pro vljublennogo malarya. Rezhisser Nadezhda Kosheverova, Lenfil'm, 1986]. Accessed 1 March 2020.

Там на неведомых дорожках. Режиссер Михаил Юзовский, Киностудия им. М. Горького, 1982 [Tam na nevedomykh dorozhkah. Rezhisser Mihail Yuzovskiy, Kinostudiya im. M. Gor'kogo, 1982], www.youtube.com/watch?v=g2f0EtkV1lI. Dostęp 1.03.2020.

Чудеса в Решетове. Режиссер Михаил Левитин, Кинокомпания Феникс фильм, 2004 [Chudesa v Reshetove. Rezhisser Mihail Levitin, Kinokompaniya Feniks fil'm, 2004], www.youtube.com/watch?v=mZZ_F0hwQKM. Dostęp 1.03.2020.

OPRACOWANIA

Frazer, James. The Golden Bough: A Study in Magic and Religion. McMillan, 1890.

Gadacz, Tadeusz. O umiejętności życia. Wydawnictwo „Znak”, 2002.

Genepp, Arnold. Obrzędy przejścia. Przeł. Beata Biały, Państwowy Instytut Wydawniczy, 2006.

Jung, Carl. Über die Archetypen des kollektiven Unbewußten. Fischer Taschenbuch Verlag, 1983.

Pajor, Kazimierz. Psychologia archetypów Junga. Wydawnictwo Psychologii i Kultury „Eneteia", 2004.

Wosien, Maria. The Russian Folk-Tale: Some Structural and Thematic Aspects. Verlag Otto Sagner, 1969.

Vedfelt, Ole. Kobiecość w mężczyźnie. Przeł. Piotr Billig. Wydawnictwo Psychologii i Kultury „Eneteia”, 2004. 
Аникин, Владимир. Русская народная сказка. „Просвещение”, 1977 [Anikin, Vladimir. Russkaya narodnaya skazka. „Prosveshcheniye”, 1977].

Аникин, Владимир. Русское устное народное творчество. Издательство „Высшая школа”, 2000 [Anikin, Vladimir. Russkoye ustnoye narodnoye tvorchestvo. Izdatel'stvo „Vysshaya shkola", 2000].

Афанасьев, Александр. Поэтические воззренияя славян на природу: опыт сравнительного изучения славянских преданий и верований в связи с мифическими сказаниями других родственных народов. В трех томах, т. 1. „Современный писатель”, 1995 [Afanas'ev, Aleksandr. Poeticheskiye vozzreniyaya slavyan na prirodu: opyt sravnitel'nogo izucheniya slavyanskikh predaniy $i$ verovaniy $v$ svyazi s mificheskimi skazaniyami drugikh rodstvennykh narodov. V trekh tomakh, t. 1. „Sovremennyy pisatel”, 1995].

Виноградова, Людмила. „Та вода, которая...” Признаковое пространство культуры, ред. Светлана Толстая, Индрик, 2002 [Vinogradova, Lyudmila. „Ta voda, kotoraya...” Priznakovoye prostranstvo kul'tury, red. Svetlana Tolstaya, Indrik, 2002].

Лулудова, Елена. „Русские народные сказки и их архетипические составляющие”. Международный журнал прикладных и фундаментальных исследований, nr 8, cz. 4, 2015, ss. 803-807 [Luludova, Elena. „Russkiye narodnyye skazki i ikh arkhetipicheskiye sostavlyayushchiye". Mezhdunarodnyy zhurnal prikladnykh i fundamental'nykh issledovaniy, $\mathrm{nr} 8$, ch. 4, 2015, pp. 803-807], applied-research.ru/ru/article/view?id=7245. Dostęp 1.03.2020.

Мелетинский, Елеазар. Избранные статьи. Воспоминания. Издательство „РГГУ”, 1998 [Meletinskiy, Eleazar. Izbrannyye stat'i. Vospominaniya. Izdatel'stvo „RGGU”, 1998].

Новиков, Николай. Образы восточнославянской волшебной сказки. „Наука”, 1974 [Novikov, Nikolay. Obrazy vostochnoslavyanskoy volshebnoy skazki. „Nauka”, 1974].

Пропп, Владимир. Исторические корни волшебной сказки. „Лабиринт”, 1998 [Propp, Vladimir. Istoricheskiye korni volshebnoy skazki. „Labirint”, 1998].

Пропп, Владимир. Морфология сказки. „АСАDEMIA”, 1928 [Propp, Vladimir. Morfologiya skazki. „ACADEMIA”, 1928].

Романова, Нелли. Женское одиночество. Вариант типологизации. [Romanova, Nelli. Zhenskoye odinochestvo. Variant tipologizatsii], cyberleninka.ru/article/v/zhenskoe-odinochestvovariant-tipologizatsii. Dostęp 1.03.2020.

Русский демонологический словарь. Составила Новичкова Татьяна. „Петербургский писатель”, 1995 [Russkij demonologicheskiy slovar'. Sostavila Novichkova Tat'yana, „Peterburgskiy pisatel'”, 1995].

Рыбаков, Борис. Древняя Русь: сказания, былины, летописи. „Лабиринт”, 1963 [Rybakov, Boris. Drevnyaya Rus': skazaniya, byliny, letopisi. „Labirint”, 1963].

Топорков, Андрей Л. Теория мифа в русской филологической науке ХХ века. Индрик, 1997 [Toporkov, Andrey L. Teoriya mifa v russkoy filologicheskoy nauke XX veka. Indrik, 1997]. 


\title{
W NIEWOLI U KOŚCIEJA NIEŚMIERTELNEGO \\ ALBO „SAMOTNOŚĆ SILNYCH KOBIET”: STUDIUM TREŚCI ROSYJSKIEJ BAJKI „MARIA MORIEWNA”
}

\author{
Streszczenie
}

Przedmiotem analiz artykułu jest wzajemna zależność kobiety i mężczyzny w cyklu przemiany: od samotności do związku małżeńskiego. Za punkt odniesienia posłużyła postać Kościeja Nieśmiertelnego, podstawowego zaś materiału źródłowego dostarczyły teksty kultury, w których Kościej się pojawia. Centrum rozważań stanowi „silna kobieta”, utożsamiana $\mathrm{z}$ archetypem wojowniczki. Za reprezentatywną postać przyjęto Marię Moriewnę z bajki o tym samym tytule.

Postawiono następujące hipotezy badawcze:

1. Kobieca tęsknota za mężczyzną stanowi swoistego rodzaju „zew”, prowokujący pojawienie się antagonisty - Kościeja.

2. „Silna kobieta” ma niektóre z cech Kościeja: gotowość do walki i bezpośredniej konfrontacji, umiejętność polegania na sobie, brak litości dla pokonanych.

3. Właściwym partnerem „silnej kobiety” jest mężczyzna „dobry i głupi”.

Analizy odsłoniły binarne pary zachowań kobiety i mężczyzny, konieczne do tego, by cyk1 rozwoju obydwojga się dopełnił: czekanie Marii Moriewny i brak pośpiechu ze strony Iwana, prośba o radę kierowana przez Iwana do Baby Jagi i poznawanie sekretu Kościeja przez Marię, budowanie siły u Iwana i rezygnacja z siły u Marii.

Wysnute wnioski odsłoniły dalsze perspektywy badawcze, takie jak:

- Analiza fenomenu samotności „silnej kobiety”, zniewolonej przez cechy reprezentowane archetypową postacią Kościeja, w ujęciu filozoficznym i namysł nad wertykalnym kierunkiem ludzkich dążeń.

- Porównanie treści bajek jako utworów literackich z treściami filmów fabularnych, z naciskiem na formę przekazu i typ relacji między nadawcą a odbiorcą.

Słowa kluczowe: bajka rosyjska; feminizm; kultura; rytuały inicjacyjne.

\section{ENSLAVED BY KOSHCHEY THE IMMORTAL, OR "THE LONELINESS OF THE STRONG WOMEN": THE UNIVERSAL WISDOM OF RUSSIAN TALE}

Su m mary

Koshchey the Immortal, one of main personages of Russian tales, is a negative character. Nevertheless, he plays a positive role in the heroes' journey in life. In this paper, special attention is devoted to female heroes. The following hypotheses are presented:

1. A woman's yearning for a man constitutes the type of situation in which Koshchey the Immortal appears. It is the kind of call that provokes the antagonist to appear.

2. A strong woman is the one who carries some of the Koshchey's qualities within her, such as an eagerness to fight and for face-to-face confrontations. She often represents a warrior type.

3. A simple but good man is the ideal partner for the woman who gets enslaved by Koshchey.

Two kinds of enslavement are distinguished: that in which she is physically taken, and that where she carries Koshchey "inside of her" and manifests this in her behaviour. A woman alone is not able to break free.

Key words: Russian tale; feminism; culture; initiation rituals. 